\author{
Andrzej Walewski \\ University of Warsaw \\ Faculty of Geography and Regional Studies \\ Department of Regional Geography \\ e-mail: awalewski@uw.edu.pl \\ Ewelina Kantowicz \\ University of Warsaw \\ Faculty of Geography and Regional Studies \\ Department of Regional Geography \\ e-mail: ekanto@uw.edu.pl
}

\title{
THE RELATIONS BETWEEN MAN AND THE NATURAL ENVIRONMENT AS THE METHODOLOGICAL BASIS FOR DELIMITATION OF REGIONS
}

\begin{abstract}
The concept of regional geography as a science examining the relations between man and the natural environment is presented. Spatial coexistence of natural and socio-economic phenomena is a premise to search for causative relations. Their theoretic fundaments are described by the principle of factors limiting human activity, diversification as the general characteristic of the natural environment having impact on man and his activity, the principle of indirect chain links, changeability of relations in time and their interactions. Among others, correlation and regression analysis, the class differences method and tests of independence are used in research on the concordance of spatial coexistence of characteristics of the natural environment and socio-economic characteristics. The issue of the relations between man and the environment, examined on different scales, is associated with issues of the geographic region. A region may be perceived as an area characterized by a similarity of relations between the natural environment and human activity.
\end{abstract}

Key words: regional geography, region, delimitation of regions, relations between man and the natural environment.

Regional geography is a discipline which provokes much controversy. On the one hand, it is described as the "crown of geographic sciences" or the "visiting card" of geography and on the other, it is depreciated for its scientific superficiality, descriptive character and compilation approach. The fundamental disagreement includes the subject and objective of regional geography. Some authors see it in the demarcation of particular areas of the earth (regions) and research on it and others treat it exclusively as an area of reference. According to some, regional geography stands at the junction 
point between the sphere of nature and human activity and examines their interrelationships. Others see two totally separate regional geographies, i.e. physical which examines physico-geographical units and economic which takes up administrative-political or economic units. Some identify regional geography with "knowledge on regions".

During the last half century, different approaches to regional geography have been considered on numerous occasions, especially issues of the subject and objective of research as well as methods being used. In Poland, several conferences were dedicated to these issues. The last was the III Forum of Polish Geographers in Poznań in 2006 as well as numerous publications, e.g., Barbag, 1959; Dumanowski, 1981; Kantowicz, Skotnicki, 1991; Kondracki, 1995; Kostrzewski, 2006; Gocłowski et al., 2008.

This article introduces the concept of regional geography as a science which examines the man-natural environment relations, as proposed by Bolesław Dumanowski (1981). The stimuli for its development may be sought, besides the cognitive motives, also in the practical use of knowledge about nature-man interrelationships. They emerge in different spatial scale as global, regional and local issues. The key idea to the presented concept of regional geography may be expressed by the catchword: "nature-man-region".

Nature (natural environment) - refers to the natural aspects of the human environment. Traditionally, geological structure, relief, water, climate, soil, plant cover and fauna are singled out. The often used term of geographic environment has a broader meaning and is used to underscore that we are also interested in the landscape components created by man.

Man - we use this term as a sort of a slogan or a mental shortcut not thinking about an individual - but rather behavior and activity of a group of people, communities and societies as well as material output of this activity, inscribed in landscape.

Region - is an ambiguous term. We refer to the tradition of a geographic region, also called a complex region, that is to a region in the natural as well as cultural and socio-economic sense. In regional geography there are two traditional interpretations of the man-nature relations, i.e. the traditional complex region ("cultural and natural area") and tradition of the functional region. The complex region is a homogeneous area in respect to nature, inhabited by a specific national or ethnic group using its resources in a specific manner. In a functional region, on the other hand, the region's binding material are functional relations. They are realized on different levels - the flow of inhabitants, produce, services and capital. In order that a functional region be treated according to the proposed concept of regional geography, this definition must be broadened by the man-nature relationships.

Search for relations between the natural environment and man and his activity has become the essence of the approach. Researching them requires isolating both phenomena. We do this, even though in reality they form a specific entirety and occur together, taking up the same space. 
We, therefore, are dealing with a procedure for identifying phenomena and next, with examining relations between them. In geography, relations are usually defined as coexistence in space, outcome in time, relations between form and function and a part and the whole. In regional geography, they are most often treated as spatial co-existence of natural and socio-economic phenomena which, according to Mill's principle of concomitant variations, becomes the premise to search for causative relations between the natural environment and human activity. Passage from dependency of a formal character to cause-effect relationships requires identification of the process or mechanism linking the examined phenomena. These processes and mechanisms in the area of the man-nature relations are usually very complex.

The theoretical basis of these relations describe such concepts as the ecological principle of limiting factors constraining human activity, diversification as a general characteristic of the natural environment which impact on man and his activity, the principle of indirect chain links, changeability of relations in time, their dualism and interaction. They were used in research carried out by regional geographers from University of Warsaw. The idea of limiting factors was used in land assessment for rural purposes and other fields of human activity, i.e. settlement, tourism (Kantowicz, 1999; Winidowa, 2000), in research on the barriers of settlement and socio-economic development (Kantowicz, 1985b), and lately also in research on "environmental risk" and its impact on man (Rucińska, 2003). The significance of diversification of the natural environment and physico-geographical borders to human activity was examined in reference to the location and durability of settlement (Dumanowski, 1968, Dumanowski, Plit, 1985; Gocłowski, 1984, 1986, 1988, 1993; Lechowicz, 2000), beginnings of agriculture (Kantowicz 1985a) and agriculture in extreme environments (Walewski, 1979,1990).

In the research were used different methods for substantiating the degree of concordance in spatial co-existence of characteristics: correlation and regression analysis, class (rang) differences method, tests of independence (Walewski, 2005). The preliminary phase of research is the selection of significant, from the perspective of a particular phenomenon, characteristics of the natural environment and the approach to expressing socio-economic phenomena. Geographical diversity was among the most often referred to characteristics of the environment, measured by the difference of particular environmental parameters in the areas of reference (Dumanowski, Plit, 1985) or appearance of physico-geographical borders and barriers. From the human perspective were taken into account: population density, distribution and durability of settlement, various aspects of land use and agriculture, density and pattern of communication and transport networks, tourism and tourist facilities, economic development and its characteristics. Indices to describe the degree of anthropogenic transformation of the environment or its degradation were also searched for.

The impact of particular characteristics or elements of the environment and their changeability in time were examined applying various methods, 
most often correlation and regression analysis and class (rang) differences. The latter method, as a modification of the rang-difference method, constitutes a comparison of the intensity of the analyzed phenomena in designated spatial units. The area of research is divided into a number of areas (plots), which may be of natural, administrative or geometric character. The value (intensity) of both of the analyzed phenomena is determined in each area. These values are next grouped in classes. All the areas (plots) are described by two values. With identical intensity of the phenomena the class difference is 0 . In the case of dissimilar intensity, it uses values other than zero (positive or negative). The greater the differences, the smaller is the concordance of the intensity of compared phenomena in a given area. We thus obtain a map presenting differences in the intensity of examined phenomena for $\mathrm{n}$ areas. The obtained picture of similarities and differences of the intensity of compared phenomena allows to identify both the general relation between these phenomena as well as to determine its spatial diversity and state where it takes place with greater and lesser force. This characteristic of the method is of particular importance because it allows to analyze spatial differences in the correlation between the examined phenomena. The method's simplicity is a value, whereas the need to use grouped data is its drawback. Besides the obvious loss of data accuracy in the grouping procedure, the method of grouping them may have significant impact on the result obtained by the class difference method. It should be aimed at that the number of classes and the number of elements (units) in corresponding classes of both phenomena be identical. When fulfillment of this premise is impossible, corrective procedures should be used (Walewski, 1997).

Among the correlation methods applied in the research on the man-nature relationship particularly useful are those methods which allow to describe not only the force and character of the correlation but also its spatial differentiation. Using the standard approach, we obtain a single value of correlation coefficient for the entire analyzed set, e.g. the whole research area. This does not inform us whether this correlation is identical throughout the area or it differs in its particular sections. To obtain such information it is necessary to divide the research area into smaller plots, calculate the correlation between comparable phenomena for each of these plots, attributing the obtained values of the correlation coefficient values to the central points of these plots and then to delineate lines of identical correlation (isocorrelates). Such a map shows the spatial diversification of correlation in the area of research.

Information about the spatial differentiation of the examined relationships may also be obtained by means of regression analysis and maps of residuals from regression. These maps show, precisely speaking, not the relationship itself but the size and character of deviations from the statistically determined values, describing the analyzed relationship. The smaller the deviations, the closer is the relation between the examined phenomena.

The reviewed methods allow examination and presentation of spatial differentiation of relationships between nature and man. The character and 
strength of these relationships may be a significant criterion to determine, within framework of research, subareas (regions) with dissimilar relationships between nature and man. For example, correlations between landforms and distribution of arable land are different in arid and humid areas. Application of this criterion allows integration of the relationships of the man-nature issue with issues regarding the region.

A region may be viewed as an area characterized by similarities of relationships between the natural environment and human activity and often also by specificity of practical problems stemming from these relations.

Pointing out the appropriateness and usefulness of delimitation of regions on the basis of relations between nature and man, it is necessary to be aware that it is not always possible because such regions do not always exist in areas of research. Sometimes, these relations may be of a non-diversified character. Under other circumstances, they may be strongly diversified but the spatial arrangement of these dissimilarities is mosaic, not allowing to set apart, on their basis, compact spatial units (regions).

Sometimes, however, such an arrangement shows evident spatial order and it is relatively easy to distinguish compact areas with different natureman relationships. Under such circumstances delimitation of regions on the basis of the character of such relations is possible and fully justified.

The presented concept of regional geography may evoke reservations. Numerous geographers consider, for example, that the man-natural environment interrelationships are the subject of interest of general geography and not only of regional geography. In reality, most definitions of geography describe its research subject in such a way. Practice shows, however, that it usually remains in the sphere of declarations and is rarely carried out.

Majority of the research carried out by geographers takes into account various aspects of either the natural environment or human activity. Studies aiming at identification of the relationships existing between them are infrequent. An exception is the research on anthropopressure. The proposed concept also carries out the often submitted premise of geographical unity.

One more reservation put forward in regard to research on the man-environment relationships is associated with questioning the possibilities of proper assessment of the role of the natural environment in human activity. Recalled are examples, most often historical, of studies which overrate or negate this significance. It seems that the arbitrariness and subjectivism of such assessments may be successfully constrained by the use of formalized methods of examining these relations. This will allow to obtain precise and objective results.

There are also opinions that the issue of the nature-man relationship is passé, because the natural environment plays an increasingly less important role in human life. It seems that the changing role of the natural environment should rather be discussed. In certain areas of human activity it is, in fact, decreasing and in others is increasing. New, not existing earlier, relations 
between nature and man are being created, e.g. impact of weather on space flights, television signal transmissions or impact of landforms on the range of mobile telecommunications. Magnitude with which such issues as climate change or depletion of natural resources are currently regarded shows that the natural environment still is a significant issue for man.

Relationship between man and the natural environment is not the exclusive domain of geographers. With increasing intensiveness, representatives of other scientific disciplines, e.g. economists or psychologists, engage themselves in it. They analyze various aspects of these relations, using numerous theoretical approaches. Taking a stance on this issue, the American geographers Gabriel Judkins, Marissa Smith and Eric Keys have written (2008) about „rediscovery of environmental causation”. They underline the need to present politicians and society with convincing arguments about shaping a new countenance of the world. Such arguments should be theoretically well justified results of indisciplinary research on the nature-man issue. Geographers may substantially contribute to such research.

\section{REFERENCES}

Barbag J., 1959, Przedmiot i zadania geografii regionalnej [Subject and tasks of regional geography], Przeglad Geograficzny, vol.31, 3-4, 495-515

Dumanowski B., 1968, The influence of geographical environments on distribution and density of population in Africa, Africana Bulletin, 9, 9-33

Dumanowski B., 1981, Geografia regionalna jako dyscyplina badawcza [Regional geography as a research discipline], Przeglad Geograficzny, vol.53, 1, 87-94

Dumanowski B., Plit F., 1985, Metoda oceny środowiska przyrodniczego na przykładzie Afryki [Method of evaluation of natural environment on example of Africa], Prace $i$ Studia Geograficzne, vol. 8, 9-40

Gocłowski A., 1984, Continuity of urban locations and the main, complex physico-geographical boundaries on the Crimean Peninsula (USSR), Miscellanea Geographica, 223-232

Gocłowski A., 1986, A method for assessing relations between the physicogeographical boundaries and location and growth of settlement, Miscellanea Geographica, 153-158

Gocłowski A., 1988, The influence of physico-geographical boundaries on settlement and settlements borders, Miscellanea Geographica, 187-191

Gocłowski A., 1993 ( $2^{\text {nd }}$ ed.), Przyrodnicze uwarunkowania lokalizacji $i$ trwałości miast na Pótwyspie Krymskim [Natural conditions of location and durability of towns in the Crimean Peninsula] (VI w. p.n.e. - XX w. n.e.], WGiSR UW, Warszawa.

Gocłowski A., Kałuski S., Kantowicz E., Walewski A., 2008, Geografia regionalna [Regional geography], [in:] Historia geografii polskiej, Jackowski A. et al. (eds.), Wyd. Naukowe PWN, Warszawa, 248-260

Judkins G., Smith M., Keys E., 2008, Determinism within human-environment research and the rediscovery of environmental causation, Geographical Journal, vol. 174, no. 1, 17-29

Kantowicz E., 1985a, Naturalne warunki rozwoju uprawy roślin na pograniczu lasu i sawanny w Afryce [Natural conditions of development of plant cultivation in the border zone between forest and savanna in Africa], Prace i Studia Geograficzne, vol. 8, 83-165

Kantowicz E., 1985b, Przyrodnicze bariery rolniczego zagospodarowania ziemi $w$ strefie suchej [Environmental limits of agricultural land reclamation in the arid zone], Dissertationes Universitatis Varsoviensis no 63, Wyd. UW, Warszawa. 
Kantowicz E., 1999, Strefa sucha - zasoby i zagrożenia rolnictwa [The arid zone - resources and hazards to agriculture], Wyd. Akademickie Dialog, Warszawa

Kantowicz E., Skotnicki M., 1991, Główne problemy i tendencje w geografii regionalnej [Key issues and trends in regional geography], [in:] Z. Chojnicki (ed.), Podstawowe problemy metodologiczne polskiej geografii, Wyd. Nauk. UAM, Poznań, 229-43

Kondracki J., 1995, O geografii regionalnej [On regional geography], Przeglad Geograficzny, vol.67, 1-2, 17-28

Kostrzewski A., (ed.), 2006, Geografia regionalna jako przedmiot badań i nauczania, [Regional geography as a subject of research and teaching], Bogucki Wyd. Naukowe, Poznań.

Lechowicz M., 2000, Location of capitals of the world and the boundaries of vegetation zones, Miscellanea Geographica, vol. 9, 165-174.

Rucińska D., 2003, Związki między ENSO a gospodarką na zachodnich wybrzeżach Ameryk [Relations between ENSO and the economy of the west coasts of the Americas], Afryka, Azja, Ameryka Łacińska, vol. 80, 149-166.

Walewski A., 1979, L'influence de l'altitude sur l'exploitation des terres cultivées en Afrique Orientale, Africana Bulletin, vol. 28, 57-82.

Walewski A., 1990, Możliwości rozwoju rolnictwa w obszarach górskich w Afryce [Possibilities of development of agriculture in the mountains areas of Africa], [in:] Środowisko $i$ rolnictwo krajów subtropikalnych, Kraków, 77-82.

Walewski A., 1997, Badanie relacji między zmiennymi o wartościach grupowanych - propozycja metodyczna [The study of the relation between the variables of classified values a methodical proposal], Prace i Studia Geograficzne, vol.19, 49-54.

Walewski A., 2005, Metody badania relacji przyroda-człowiek [Man-nature interrelationship study methods], Prace $i$ Studia Geograficzne, vol. 34, 75-85.

Winidowa J., 2000, Prace magisterskie na temat potencjalnych, optymalnych i rzeczywistych obszarów wybranych upraw wykonane w Zakładzie Geografii Regionalnej [Master's theses on the potential, optimum and real areas of chosen crop growing written in the the Department of Regional Geography] , Afryka, Azja, Ameryka Eacińska, vol. 76, 57-77

English translation: Matgorzata Miłaszewska 